5. Охунов А.О. Комплексное хирургическое лечение гнойно-некротических форм диабетической стопы// Научно-практическая конференция с международным участием актуальные вопросы хирургической инфекции посвященная 140-летию СПбГБУЗ «Городская больница № 14» 16ноября 2016года, Санкт-Петербург. - С. 79-81.

6. Охунов А.О., Пулатов У.И., Охунова Д.А. Случай особенности клинического течения гнойновоспалительного заболевания мягих тканей на фоне сахарного диабета// European research: innovation in science, education and technology London, United Kingdom, 07-08 июня 2018 - С. 19-22.

7. Пулатов У.И, Бабаджанов Б.Д., Охунов А.О. Эффективные методы диагностики генерализации инфекции при гнойно-воспалительных заболеваниях мягких тканей на фоне сахарного диабета//Вестник Ташкентской Медицинской Академии, - 2012. - №3. - С. 94-98.

8. Bakker K, Apelqvist J, Lipsky BA, Van Netten JJ; International Working Group on the Diabetic Foot. The 2015 IWGDF Guidance Documents on Prevention and Management of Foot Problems in Diabetes: Development of an Evidence-Based Global Consensus. Diabetes Metab Res Rev. 2016 Jan; 32 Suppl 1:26.

9. Lipsky BA, Apelqvist J, Bakker K, Van Netten JJ, Schaper NC. Diabetic foot disease: moving from roadmap to journey. Lancet Diabetes Endocrinol. 2015 Sep, 3(9): 674-675.

10. Peyrot M. et al. Diabetes Attitudes Wishes and Needs 2 (DAWN2): a multinational, multi-stakeholder study of psychosocial issues in diabetes and person-centered diabetes care // Diabetes Res Clin Pract. 2013. Vol. 99(2). P. 174-184.

\title{
Павленко Н.В. \\ Контроль качества лекарственных форм для детей в условиях аптеки
}

Северо-Осетинский государственный университет имени К.Л.Хетагурова (Россия, Владикавказ)

doi: $10.18411 / \mathrm{j}-05-2021-55$

\section{Аннотация}

На современном этапе выделяют особую группу лекарственных средств, специально предназначенных для использования в детской практике. К препаратам, применяемым у детей, предъявляются особые требования и качества. Прежде всего, это обусловлено анатомо-физиологическими особенностями детского организма, которые в значительной степени отличаются от организма взрослого.

детей

Ключевые слова: Лекарственная форма, требования, качества, контроль, для

\section{Abstract}

At the present stage, a special group of medicines is distinguished, specially designed for use in children's practice. Special requirements and qualities are imposed on the drugs used in children. First of all, this is due to the anatomical and physiological characteristics of the child's body, which are largely different from the adult's body.

Keywords: Dosage form, requirements, quality, control, for children

Согласно приказа № 214 от 16 июля 1997 г. «Все лекарственные средства, изготовленные в аптеках (в том числе гомеопатических) по индивидуальным рецептам или требованиям лечебных организаций, в виде внутриаптечной заготовки, фасовки, а также концентраты и полуфабрикаты подвергаются внутриаптечному контролю: письменному, органолептическому и контролю при отпуске - обязательно»

Органолептический контроль заключается в проверке лекарственной формы по показателям: «Описание» (внешний вид, цвет, запах), однородность, отсутствие видимых механических включений (в жидких лекарственных формах).

Полному химическому контролю (даже при отсутствии в штате аптеки провизора-аналитика) подвергаются лекарственные формы, предназначенные для новорожденных детей. При отсутствии методик количественного анализа данных лекарственных форм, они должны быть проверены качественным анализом. Как исключение, для новорожденных детей изготовление лекарственных форм, сложных по 
идет составу и не имеющих методик качественного и количественного анализа, производится авто в авто присутствии авто провизора -аналитика или провизора технолога «под наблюдением».

На все лекарственные средства, отпускаемые в детские отделения лечебных организаций, - надпись «Детское».

Требования на лекарственные препараты для новорожденных детей выписываются на отдельных бланках с обозначением «Для новорожденных», а рецепты - с указанием точного возраста ребенка.

После стерилизации все лекарственные препараты оформляют этикетками «Внутреннее» или «Наружное», «Стерильно» или «Асептически приготовлено», а также соответствующими предупредительными этикетками. На этикетках указывают возраст ребенка.

Растворы внутреннего употребления для идет детей изготавливаются в асептических условиях, массообъемным способом на очищенной воде без добавления стабилизаторов или консервантов.

Подготовка персонала, помещений, оборудования, флаконов, вспомогательных материалов проводится в соответствии с санитарными требованиями, утвержденными приказом Минздрава № 581. После изготовления растворы фильтруют, разливают во флаконы, укупоривают резиновыми пробками и металлическими колпачками под обкатку, стерилизуют насыщенным водяным паром под давлением 1,1 кгс/см2 $\left(120{ }^{\circ} \mathrm{C}\right)$. Стерилизация текучим паром при $100{ }^{\circ} \mathrm{C}$ допускается только в тех случаях, когда в действующей нормативно-технической документации этот метод указан как единственно возможный.

Вскрытие и розлив растворов в аптеке должны осуществляться в стерильные флаконы в условиях асептики. Вскрытые флаконы идет с растворами используются немедленно и хранению не подлежат.

$$
* * *
$$

1. Ажгихин И.С. Технология лекарств. Москва: «Медицина» - 1980, с.440

2. Баранов А.А. Здоровье детей России: научные и организационные приоритеты //Педиатрия. 2013, N.3. 4-7

3. $\quad$ Государственная фармакопея, XIV издание - Москва: 2015г., 7020с. Обновлёна 30 ноября 2018.

4. Гельперина С. Э. Системы доставки лекарственных веществ на основе полимерных наночастиц / С. Э. Гельперина, В. И. Швец // Биотехнология. - 2014.-No3.-С. 8-23.

5. Клинические аспекты фотодинамической терапии / А. Ф. Цыб и др. - Калуга : Изд-во науч. лит. Н. Ф. Бочкаревой, 2014. 204 с.

6. Клиническая фармакология: Учеб. / Под. ред. В.Г. Кукеса. - М.: ГЭОТАР-МЕД, 2009.-290с.

7. Крылов, Ю.Ф. Энциклопедия лекарств / Ю.Ф. Крылов. - М.: РЛС-2007. - 1503 с.

\section{Павленко Н.В., Козонова 3.Г.} Полезные свойства калины

Северо-Осетинский государственный университет имени К.Л.Хетагурова (Россия, Владикавказ)

doi: $10.18411 / \mathrm{j}-05-2021-56$

\section{Аннотация:}

Существует около 8 видов калины, особое место занимает калина обыкновенная, которая обладает полезными свойствами : укрепляет иммунитет,лечит простудные заболевания,является прекрасным отхаркивающим средством,профилактика и лечение авитаминоза,предотвращает развитие раковых клеток,предотвращает развитие аллергических реакций,является мочегонным и кровоостанавливающим средством.

Ключевые слова: калина обыкновенная ,витамины , гликозид , косметология. 